\title{
Experimental studies of spent fuel burn-up in WWR-SM reactor
}

\author{
Sh.A.Alikulov ${ }^{\mathrm{a}}$, S.A.Baytelesov ${ }^{\mathrm{a}}$, A.F.Boltaboev ${ }^{\mathrm{a}}$, F.R.Kungurov ${ }^{\mathrm{a}}$, \\ H.O.Menlove ${ }^{b}$, W.O'Connor ${ }^{b}$, B.S.Osmanov ${ }^{c, *}$, U.S.Salikhbaev ${ }^{a}$
}

\begin{abstract}
The article reports the results of ${ }^{235} \mathrm{U}$ burn-up measurements using ${ }^{137} \mathrm{Cs}$ activity technique for 12 nuclear fuel assemblies of WWR-SM research reactor after 3-year cooling time. The discrepancy between the measured and the calculated burn-up values was about $3 \%$. To increase the reliability of the data and for cross-check purposes, neutron measurement approach was also used. Average discrepancy between two methods was around $12 \%$.

Keywords: research reactor, IRT-4M fuel, burn-up, ${ }^{137} \mathrm{Cs}$, neutron measurements.

\section{Introduction}

At first, the main analysis methods for spent nuclear fuel were radiochemical ones which required the destruction of the sample. These techniques were both time and money consuming. But soon, the so-called non-destructive analysis methods appeared which are in use nowadays and are constantly improving. These approaches are employed for the measurements of various characteristics of spent nuclear fuel assemblies amongst which the burn-up is one of the most important. It is used for fuel supply regulations, for check-up of various reactor calculations and for ensuring safe reactor operation (criticality). There are different techniques for measuring this parameter - e.g. alpha-spectrometry (Kihsoo et al., 2007). One of the widespread approaches to study the spent fuel parameters is the gamma-activity measurement of long-lived fission products (Morrison et al., 1957). One of such products is ${ }^{137} \mathrm{Cs}$ with the half-life of 30.17 years, distinctive gamma-peak at $662 \mathrm{keV}$ and the yield of $6.2 \%$ at ${ }^{235} \mathrm{U}$ fission. Accumulation of ${ }^{137} \mathrm{Cs}$ in a reactor is directly proportional to neutron flux and, thus, to the number of fissioning ${ }^{235} \mathrm{U}$ nuclei. This isotope has good characteristics for its usage in the determination of spent fuel parameters, namely: low cross-section for radiative neutron capture, approximately equal yields
\end{abstract}


for uranium and plutonium fission, large half-life compared to fuel irradiation time, low migration inside fuel element, and relatively high energy of emitted gamma-radiation. This nuclide is the largest contributor to gamma-activity of spent fuel assemblies after long cooling times. All of the above-mentioned resulted in extensive application of this technique in nuclear energy domain (Suzaki et al., 1979; Phillips, et al., 1980; Kristoff and Pregl, 1990; Wang et al., 1990; Fensin et al., 2009).

Another approach for the measurement of initial enrichment and concentration of ${ }^{235} \mathrm{U}$ in nuclear fuel is through neutron measurement (Phillips et al., 1983; Reilly et al., 1991). Both "active" (irradiation of spent fuel by neutron source) and "passive" (neutrons from spontaneous fission) methods are employed. Frequently, gamma and neutron measurements are coupled (Toubon et al., 2006).

This manuscript reports the results on spent fuel burn-up measurement using two abovedescribed techniques (gamma and neutron) for 12 spent fuel assemblies from WWR-SM research reactor (cooling times for all assemblies are around 3 years) and their comparison to operator-reported values.

\section{Experimental technique}

WWR-SM research reactor of the Institute of Nuclear Physics (INP) was put into operation on September 10, 1959 with the power of 2 MW. In 1978, the power was increased to 10 MW due to the conversion to $90 \%$ enriched fuel. In 2009, the conversion to low-enriched (19.75\%) fuel IRT-4M (www.nccp.ru/products/fuel_for_research_reactors/fuel/) was performed. The reactor contains 24 fuel assemblies providing neutron flux of $10^{13}-10^{14}$ neut $\mathrm{cm}^{2} \mathrm{~s}$ in the active zone (www.inp.uz). 9 horizontal and 30 vertical channels provide neutron beams for various experiments.

For the measurements with cesium technique, one needs the detector with good energy resolution since the spent fuel assembly is a complex source of gamma-radiation having numerous spectral peaks. We used HP-Ge detector (www.canberra.com/products/detectors/pdf/SEGe-detectors-C40021.pdf) (relative efficiency $15 \%$, FWHM - $0.825 \mathrm{keV} / 122 \mathrm{keV}$ and $1.8 \mathrm{keV} / 1.3 \mathrm{MeV}$ ) with InSpector-2000 multichannel analyzer (www.canberra.com/products/radiochemistry_lab/pdf/InSpector-2000-SS-C20387.pdf) and Genie-2000 software (www.canberra.com/products/radiochemistry_lab/genie-2000software.asp) for processing of spectra. The detector was placed inside a "dry" channel (hollow aluminum tube) and positioned in the storage pool at the depth of $5 \mathrm{~m}$ and at the distance of 50 $\mathrm{cm}$ from the measured assembly (at closer distance, the detector can not handle high radiation 
fluxes). The center of the detector was aligned with the vertical center of the measured fuel assembly.

The background spectrum was recorded for its subsequent subtraction from the measured one. Then, the reference fuel assembly (with the exact construction as the measured assembly) with the known burn-up value was brought to the detector and its gamma-spectrum was recorded. The activity of ${ }^{137} \mathrm{Cs}$ in the reference sample was deduced from $662 \mathrm{keV}$ peak with background subtraction and correcting for the amount decayed during cooling time.

Also, the correction was introduced for detector efficiency which depends on the detector type (its size, configuration, material, etc), on the energy of gamma-quanta and on the geometry of the measurement. Strictly speaking, one needs to know the efficiency of every detector for any energy and any geometry. In reality, the efficiency of a certain detector is measured for several values of energy and the obtained values are approximated by some convenient function, e.g. polynomial which allows to calculate the efficiency for any intermediate energy values. We employed several reference gamma sources $\left({ }^{57} \mathrm{Co},{ }^{133} \mathrm{Ba},{ }^{137} \mathrm{Cs},{ }^{241} \mathrm{Am},{ }^{54} \mathrm{Mn}\right)$ in various standard geometries to plot the dependence of detector registration efficiency on $\gamma$-quanta energy. Finally, the correction for quantum yield of the measured gamma-line was introduced.

Taking into account the obtained specific activity of ${ }^{137} \mathrm{Cs}(3.2 \mathrm{TBq} / \mathrm{g})$ and knowing its fission yield (6.2\%), we can determine the mass of ${ }^{235} \mathrm{U}$ in the reference fuel assembly. Next, the studied fuel assemblies were measured while keeping the exact experimental geometry as in the reference sample measurement. This allows us to exclude the corrections caused by absorption of the radiation in intermediate materials ${ }^{1}$ and by experimental geometry (solid angle, etc). Finally, the mass of uranium in the measured samples was determined by taking a simple ratio to the reference fuel assembly.

The studies on migration of cesium inside fuel element are known (Forsyth et al., 1967) which should affect the results of these measurements. However, in our opinion, this effect is small and lies within the measurement errors which allows us to neglect it and restrain from its further investigation.

\footnotetext{
${ }^{1}$ The energy of $662 \mathrm{keV}$ implies that this method studies mainly outer layer of fuel assembly (e.g. for the fuel element of $1 \mathrm{~cm}$ in diameter, $39 \%$ of $662 \mathrm{keV}{ }^{137} \mathrm{Cs}$ radiation is absorbed within the fuel element (Phillips, 1991)). Despite this, the studies show that after long irradiation times, the burnt mass of uranium is relatively evenly distributed within the fuel element (14\% correction in (Menlove et al., 2012) ) since the thermal-neutron flux on the inner regions of the fuel assembly is about the same as the outer regions. So the gamma yield from the outer layers is representative of the entire assembly.
} 
For the cross-check of the data obtained by cesium technique, we used the measurement results of the same fuel assemblies obtained by registering neutron radiation from actinides formed in radiative neutron capture reactions. The main contribution to this radiation comes from the isotopes of ${ }^{240} \mathrm{Pu},{ }^{242} \mathrm{Cm}$ and ${ }^{244} \mathrm{Cm}$ (Goldstein, 1987). The neutron counter developed at Los Alamos National Laboratory (Menlove et al., 2008) was employed. This counter can be used for both "passive" and "active" (AmLi-source) neutron measurements, for neutron coincidence counting, and for gross-gamma counting. We used the results of "passive" and "active" measurements where the "pure" neutron activity was obtained by subtracting of passive neutron background and of AmLi-source own activity. The detailed description of this technique is given in (Menlove et al., 2012).

\section{Results and discussion}

Table 1 gives the results of ${ }^{235} \mathrm{U}$ burnt mass measurement with the above-described cesium technique.

Table 1. Measurement results of ${ }^{137} \mathrm{Cs}$ activity, ${ }^{235} \mathrm{U}$ mass and burn-up in spent nuclear fuel.

\begin{tabular}{|c|c|c|c|c|c|c|c|}
\hline $\begin{array}{c}\text { Number } \\
\text { of spent } \\
\text { fuel } \\
\text { assembly }\end{array}$ & ${ }^{235} \mathrm{U}$ initial mass & $\begin{array}{l}{ }^{137} \mathrm{Cs} \text { activity at the } \\
\text { day of discharge, } \mathrm{Cu}\end{array}$ & $\begin{array}{l}{ }^{137} \mathrm{Cs} \\
\text { mass, g }\end{array}$ & $\begin{array}{c}\text { Measured } \\
\text { burnt mass of } \\
{ }^{235} \mathrm{U}, \mathrm{g}\end{array}$ & $\begin{array}{c}{ }^{235} \mathrm{U} \text { burn- } \\
\text { up, } \%\end{array}$ & $\begin{array}{c}\text { Operator- } \\
\text { reported burnt } \\
\text { mass of }{ }^{235} \mathrm{U}, \mathrm{g}\end{array}$ & $\begin{array}{c}\text { Measurement } \\
\text { error, } \%\end{array}$ \\
\hline 1 & 314.1 & 515 & 5.95 & 96.04 & 31.57 & 99.16 & 3.25 \\
\hline 2 & 305.3 & 652 & 7.54 & 121.59 & 41.1 & 125.48 & 3.20 \\
\hline 3 & 304.4 & 887 & 10.26 & 165.42 & 56.1 & 170.77 & 3.24 \\
\hline 4 & 301.6 & 915 & 10.58 & 170.64 & 58.42 & 176.19 & 3.25 \\
\hline 5 & 308.1 & 949 & 10.97 & 176.98 & 59.3 & 182.7 & 3.23 \\
\hline 6 & 305.5 & 950 & 10.98 & 177.17 & 59.9 & 182.99 & 3.29 \\
\hline 7 & 300.2 & 936 & 10.82 & 174.56 & 60.02 & 180.18 & 3.22 \\
\hline 8 & 310.8 & 975 & 11.27 & 181.83 & 60.4 & 187.72 & 3.24 \\
\hline 9 & 303.3 & 956 & 11.05 & 178.29 & 60.7 & 184.1 & 3.26 \\
\hline 10 & 303.2 & 980 & 11.33 & 182.76 & 62.22 & 188.65 & 3.22 \\
\hline 11 & 306.7 & 997 & 11.53 & 185.93 & 62.6 & 191.99 & 3.26 \\
\hline 12 & 314.8 & 1180 & 13.64 & 220.06 & 71.94 & 226.47 & 2.91 \\
\hline
\end{tabular}

The above data indicated the high accuracy of this technique: for 12 spent fuel assemblies the discrepancy between the measured and operator-reported values of ${ }^{235} \mathrm{U}$ burnt mass is about $3 \%$. Also, we can note that, in all cases, the operator-reported values are higher than the measured ones which, probably, is caused by certain systematic error in measurement or calculations. 
Table 2 lists the results of comparing two methods: cesium and neutron (single neutrons $\mathrm{N}_{\text {single }}$ and coincidence neutrons - $\mathrm{N}_{\text {coin }}$ ). Since the latter technique directly measures the residual mass of ${ }^{235} \mathrm{U}$, the data of cesium measurement was brought to similar format (the difference between the second and the fifth columns in Table 1).

Table 2. Comparison of cesium and neutron techniques.

\begin{tabular}{cccccc}
\hline $\begin{array}{c}\text { Number of Residual mass of } \\
\text { spent fuel } \\
\text { assembly }\end{array}$ & $\begin{array}{c}\text { Residual mass of } \\
{ }^{235} \mathrm{U} \text { from Cs, } \mathrm{g}\end{array}$ & $\begin{array}{c}\text { Residual mass of } \\
{ }^{235} \mathrm{U} \text { from } \mathrm{N}_{\text {single }}, \mathrm{g}\end{array}$ & $\begin{array}{c}\text { Difference between Cs } \\
\text { and } \mathrm{N}_{\text {single }}, \%\end{array}$ & $\begin{array}{c}\text { Difference between Cs } \\
\text { and } \mathrm{N}_{\text {coin }}, \%\end{array}$ \\
\hline 1 & 218.06 & 180.4 & 200.41 & 17.27 & 8.09 \\
\hline 2 & 183.71 & 154.29 & 158.25 & 16.01 & 13.86 \\
\hline 3 & 138.98 & 131.93 & 124.19 & 5.07 & 10.64 \\
\hline 4 & 130.96 & 132.69 & 127.01 & -1.32 & 3.02 \\
\hline 5 & 131.12 & 129.72 & 120.48 & 1.07 & 10.37 \\
\hline 6 & 128.3 & 93.24 & 115.02 & 27.35 & 4.84 \\
\hline 7 & 125.4 & 114.72 & 119.56 & 8.69 & 7.51 \\
\hline 8 & 128.7 & 122.92 & 119.29 & 4.69 & -5.85 \\
\hline 9 & 125.1 & 90.61 & 107.48 & 27.52 & 30.49 \\
\hline 10 & 120.4 & 122.87 & 127.48 & -2.02 & 27.21 \\
\hline 12 & 120.7 & 91.95 & 83.95 & 23.86 & -2.06 \\
\hline
\end{tabular}

As it can be seen from Table 2, discrepancy between two approaches can be up to $30 \%$. In our opinion, this can be caused by the difference in the geometry of the measurement as well as the measurements themselves. Moreover, the neutron measurement focused on the center region of the fuel assembly, and as the burnup gets large, the ${ }^{235} \mathrm{U}$ in the center region is depleted, so the neutron measurement error is amplified. This causes the larger percent difference in Table 2 for the higher burnup assemblies. Future neutron measurements will use a scanning procedure to better interrogate the entire ${ }^{235} \mathrm{U}$ mass. Despite this, the average discrepancy between cesium and neutron methods does not exceed $12 \%$.

\section{Conclusion}

The obtained experimental results show that the technique of nuclear fuel burn-up determination from fission product activity (in this case $-{ }^{137} \mathrm{Cs}$ ) is not difficult in implementation but, at the same time, is quite accurate. Discrepancy with operator-reported values does not exceed $4 \%$. At the cross-comparison of the results with neutron-based measurements, average discrepancy was around $12 \%$. 


\section{Acknowledgements}

This work was funded by the State Science and Technology Program of Uzbekistan under the contract number F2-FA-F112 "Experimental studies of properties and states of nuclear matter at high and low energies". Authors would also like to acknowledge the Department of Energy National Nuclear Security Administration's (NNSA's) Office of Nonproliferation and International Security (NIS), Office of Nuclear Verification for their support.

\section{References}

Fensin, M. L., Tobin, S.J., Menlove, H.O., Swinhoe, M.T., 2009. Quantifying the passive gamma signal from spent nuclear fuel in support of determining the plutonium content in spent nuclear fuel with nondestructive assay. Trans. INMM, Tucson, Arizona, July 12-16, 2009, pp.806-815.

Forsyth, R.S., Blackadder, W.H., Ronqvist, N., 1967. Burn-up determination by highresolution gamma spectrometry fission product migration studies. Report AE-272, Aktiebolaget Atomenergi AB.

Goldstein, N.P., 1987. Reactivity measurements of spent fuel assemblies using a burnup meter. Trans. Am. Nucl. Soc. 55, 401-402.

Kihsoo, J., Han, S.H., Song, B.C., Lee, C.H., Ha, Y.K., Song, K., 2007. Inductively coupled plasma mass spectrometry for the determination of ${ }^{237} \mathrm{~Np}$ in spent nuclear fuel samples by isotope dilution method using ${ }^{239} \mathrm{~Np}$ as a spike. Nucl. Eng. Technol. 39 (5), 673-682.

Kristoff, E., Pregl, G., 1990. Gamma spectrometric assessment of nuclear fuel. Nucl. Instr. and Meth. in Phys. Res. A 297, 507-513.

Menlove, H.O., Swinhoe, M.T., Marlow, J.B., Rael, C.D., 2008. Advanced experimental fuel counter calibration and operation manual. Los Alamos National Laboratory, report LA14359-M.

Menlove, H.O., Marlow, J., Miller, K., Rael, C., Swinhoe, M., O’Connor, W., Sobolev, T., Zarucki, R., Lebrun, A., Van Schijndel, E., Yavuz, U., Salikhbaev, U., Baytelesov, S., Alikulov, S., Boltabaev, A., 2012. Field tests of the AEFC for the verification of research reactor spent fuel at the WWR-SM reactor at the Institute of Nuclear Physics (INP) Uzbekistan. LA-UR $12-21422$.

Morrison, G.H., Cosgrove, J.F., 1957. Determination of uranium-235 by gamma scintillation spectrometry. Anal. Chem. 29 (12), 1770-1771. 
Phillips, J.R., Halbig, J.K., Lee, D.M., Beach, S.E., Bement, T.R., Dermendjiev, E., Hatcher, C.R., Kaieda, K., Medina, E.G., 1980. Application of nondestructive gamma-ray and neutron techniques for the safeguarding of irradiated fuel materials. Los Alamos National Laboratory, report LA-8212.

Phillips, J.R., Bosler, G.E., Halbig, J.K., Klosterbuer, S.F., Menlove, H.O., 1983. Experience using a spent-fuel measurement system. Proceedings of the Institute of Nuclear Materials Management, 24th Annual Meeting, pp.175.

Phillips, J.R., 1991. Irradiated Fuel Measurements. In "Passive non-destructive assay of nuclear materials", Riely, D., Ensslin N., Smith, H. Jr., Kreiner, S., Eds., NUREG/CR-5550, LAUR-90-72,Washington, D.C., pp. 529-562.

Reilly, D., Ensslin, N., Smith, H. Jr., Kreiner, S., 1991. Passive non-destructive assay of nuclear materials. Reports NUREG/CR-5550 and LA-UR-90-732, US Nuclear Regulatory Commission and Los Alamos National Laboratory.

Suzaki, T., Tsuruto, H., Matsura, S., 1979. Non-destructive gamma-ray spectrometry and analysis on spent fuel assemblies of the JPDR-I core. Japan Atomic Energy Research Institute, report JAERI-memo 8164.

Toubon, H., Pin, O., Lebrun, A., Oriol, 1., Saurel, N., Gain, T., 2006. Burn-up measurements coupling gamma spectrometry and neutron measurement. Canberra Tech. Doc.

Wang, T., Hsu, D., Tseng, C., 1990. Feasibility studies on iterative methods of fuel burnup estimation using gamma-ray spectrometry. App. Rad. Isot. 41(1), 41-47. 
Table 1. Measurement results of ${ }^{137} \mathrm{Cs}$ activity, ${ }^{235} \mathrm{U}$ mass and burn-up in spent nuclear fuel.

\begin{tabular}{|c|c|c|c|c|c|c|c|}
\hline $\begin{array}{l}\text { Number } \\
\text { of spent } \\
\text { fuel } \\
\text { assembly }\end{array}$ & ${ }^{235} \mathrm{U}$ initial mass & $\begin{array}{l}{ }^{137} \mathrm{Cs} \text { activity at the } \\
\text { day of discharge, } \mathrm{Cu}\end{array}$ & $\begin{array}{l}{ }^{137} \mathrm{Cs} \\
\text { mass, } \mathrm{g}\end{array}$ & $\begin{array}{c}\text { Measured } \\
\text { burnt mass of } \\
{ }^{235} \mathrm{U}, \mathrm{g}\end{array}$ & $\begin{array}{l}{ }^{235} \text { U burn- } \\
\text { up, \% }\end{array}$ & $\begin{array}{c}\text { Operator- } \\
\text { reported burnt } \\
\text { mass of }{ }^{235} \mathrm{U}, \mathrm{g}\end{array}$ & $\begin{array}{l}\text { Measurement } \\
\text { error, } \%\end{array}$ \\
\hline 1 & 314.1 & 515 & 5.95 & 96.04 & 31.57 & 99.16 & 3.25 \\
\hline 2 & 305.3 & 652 & 7.54 & 121.59 & 41.1 & 125.48 & 3.20 \\
\hline 3 & 304.4 & 887 & 10.26 & 165.42 & 56.1 & 170.77 & 3.24 \\
\hline 4 & 301.6 & 915 & 10.58 & 170.64 & 58.42 & 176.19 & 3.25 \\
\hline 5 & 308.1 & 949 & 10.97 & 176.98 & 59.3 & 182.7 & 3.23 \\
\hline 6 & 305.5 & 950 & 10.98 & 177.17 & 59.9 & 182.99 & 3.29 \\
\hline 7 & 300.2 & 936 & 10.82 & 174.56 & 60.02 & 180.18 & 3.22 \\
\hline 8 & 310.8 & 975 & 11.27 & 181.83 & 60.4 & 187.72 & 3.24 \\
\hline 9 & 303.3 & 956 & 11.05 & 178.29 & 60.7 & 184.1 & 3.26 \\
\hline 10 & 303.2 & 980 & 11.33 & 182.76 & 62.22 & 188.65 & 3.22 \\
\hline 11 & 306.7 & 997 & 11.53 & 185.93 & 62.6 & 191.99 & 3.26 \\
\hline 12 & 314.8 & 1180 & 13.64 & 220.06 & 71.94 & 226.47 & 2.91 \\
\hline
\end{tabular}


Table 2. Comparison of cesium and neutron techniques.

\begin{tabular}{cccccc}
\hline $\begin{array}{c}\text { Number of Residual mass of } \\
\text { spent fuel } \\
\text { assembly }\end{array}$ & $\begin{array}{c}\text { Residual mass of } \\
{ }^{235} \mathrm{U} \text { from Cs, }\end{array}$ & $\begin{array}{c}\text { Residual mass of } \\
{ }^{235} \mathrm{U} \text { from } \mathrm{N}_{\text {single }}, \mathrm{g}\end{array}$ & $\begin{array}{c}\text { Difference between Cs } \\
\text { and } \mathrm{N}_{\text {single }}, \%\end{array}$ & $\begin{array}{c}\text { Difference between Cs } \\
\text { and } \mathrm{N}_{\text {coin }}, \%\end{array}$ \\
\hline 1 & 218.06 & 180.4 & 200.41 & 17.27 & 8.09 \\
\hline 2 & 183.71 & 154.29 & 158.25 & 16.01 & 13.86 \\
\hline 3 & 138.98 & 131.93 & 124.19 & 5.07 & 10.64 \\
\hline 4 & 130.96 & 132.69 & 127.01 & -1.32 & 3.02 \\
\hline 5 & 131.12 & 129.72 & 120.48 & 1.07 & 8.11 \\
\hline 6 & 128.3 & 93.24 & 115.02 & 27.35 & 10.37 \\
\hline 7 & 125.4 & 114.72 & 119.56 & 8.69 & 4.84 \\
\hline 8 & 128.7 & 122.92 & 119.29 & 4.69 & 14.03 \\
\hline 9 & 125.1 & 90.61 & 107.48 & 27.52 & -5.85 \\
\hline 10 & 120.4 & 122.87 & 127.48 & -2.02 & 30.49 \\
\hline 11 & 120.7 & 91.95 & 83.95 & 23.86 & 27.21 \\
\hline 12 & 94.4 & 96.69 & 68.96 & -2.06 & 7.51 \\
\hline
\end{tabular}

